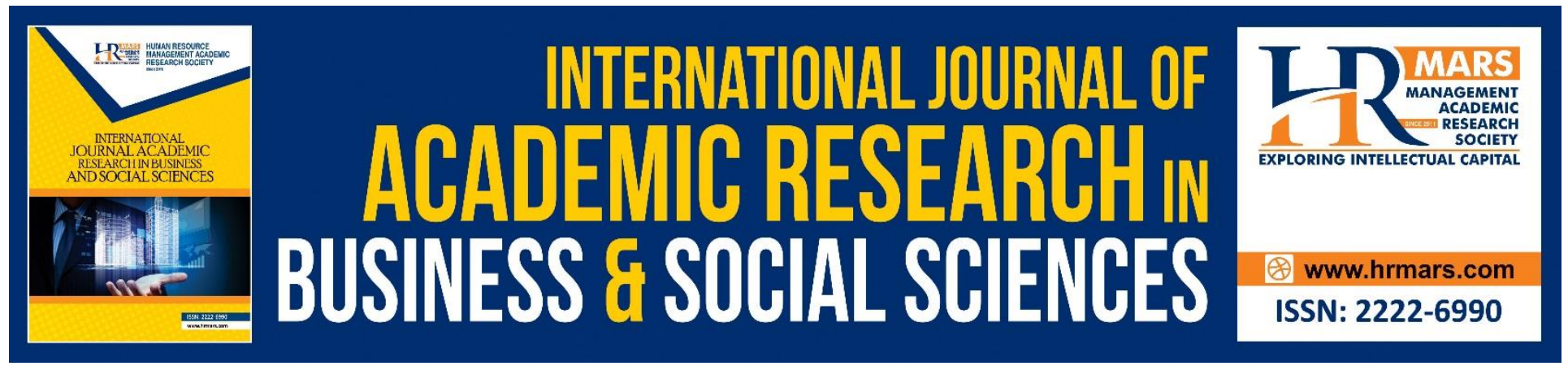

\title{
A Conceptual Framework of ERM Practices among SMEs IN Malaysia
}

Mohd Sadad Mahmod, KhairulAfzan Aziz, Ahmad Shukri Yazid, Norfadzilah Rasid, Fauzilah Salleh, Puspa Liza Ghazali and Suraya Mahmood

To Link this Article: http://dx.doi.org/10.6007/IJARBSS/v8-i11/5163

DOI: $10.6007 /$ IJARBSS/v8-i11/5163

Received: 17 Oct 2018, Revised: 29 Nov 2018, Accepted: 06 Dec 2018

Published Online: 07 Dec 2018

In-Text Citation: (Mahmod et al., 2018)

To Cite this Article: Mahmod, M. S., Aziz, K., Yazid, A. S., Rasid, N., Salleh, F., Ghazali, P. L., \& Mahmood, S. (2018). A Conceptual Framework of ERM Practices Among SMEs In Malaysia. International Journal of Academic Research in Business and Social Sciences, 8(11), 1209-1221.

Copyright: (C) 2018 The Author(s)

Published by Human Resource Management Academic Research Society (www.hrmars.com)

This article is published under the Creative Commons Attribution (CC BY 4.0) license. Anyone may reproduce, distribute, translate and create derivative works of this article (for both commercial and non-commercial purposes), subject to full attribution to the original publication and authors. The full terms of this license may be seen at: $\underline{\text { http://creativecommons.org/licences/by/4.0/legalcode }}$

Vol. 8, No. 11, 2018, Pg. 1209 - 1221

Full Terms \& Conditions of access and use can be found at http://hrmars.com/index.php/pages/detail/publication-ethics 


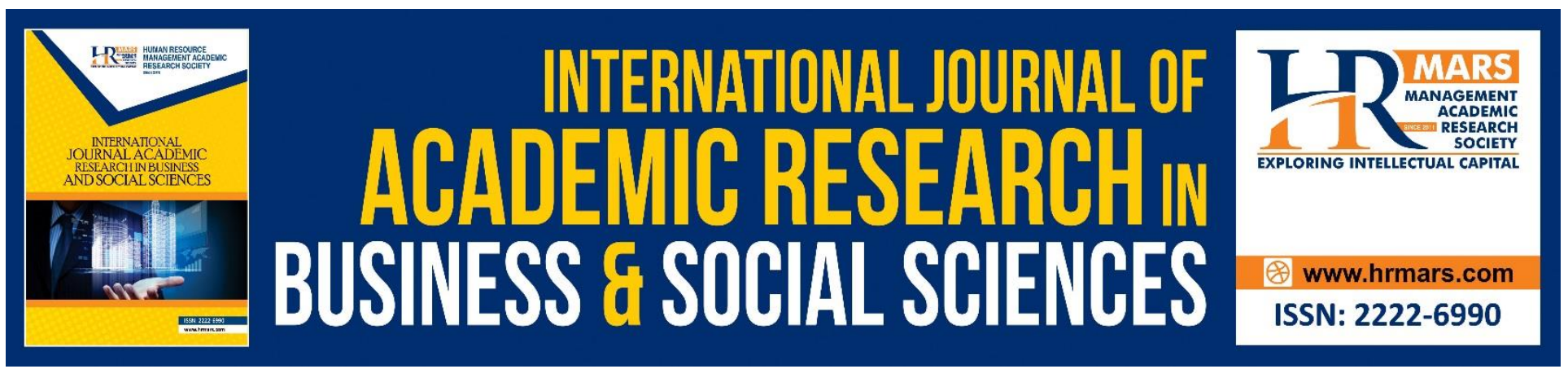

\title{
A Conceptual Framework of ERM Practices among SMEs IN Malaysia
}

\section{${ }^{1}$ Mohd Sadad Mahmod, ${ }^{2}$ KhairulAfzan Aziz, ${ }^{3}$ Ahmad Shukri Yazid, ${ }^{4}$ Norfadzilah Rasid, ${ }^{5}$ Fauzilah Salleh, ${ }^{6}$ Puspa Liza Ghazali and ${ }^{7}$ Suraya Mahmood}

1,3,4,5,6,7Faculty of Economics and Management Sciences, Universiti Sultan Zainal Abidin (Unisza),

Gong Badak Campus, 21300 Kuala Terengganu, Malaysia

${ }^{2}$ Research Institute for Islamic Products \&Civilisation (INSPIRE)

Universiti Sultan Zainal Abidin (Unisza), Gong Badak Campus, 21300 Kuala Terengganu, Malaysia

Corresponding Author:khairulafzan@gmail.com

\begin{abstract}
According to the World Bank research involving small and medium enterprises (SMEs) from 104 developing countries has found that SMEs have the largest shares of job creation, highest sales growth and employment growth compare to large firm. However, large firm is more productive. Low productivity is one of the symptoms of SMEs failure or crisis and part of the risk. Similarly, SMEs in Malaysia involvements in business expose themselves to risks. Hence, SMEs need risk management. The concept of risk management evolves over the years and now being referred as Enterprise Risk Management (ERM). ERM can be defined as an integrated approach of mitigating risk to achieve business objectives and attain competitive advantage. A review of current literature showed that the adoption of ERM contribute to large firm performance. However studies that have been conducted to examine ERM adoption among SMEs and its performance are still lacking. Furthermore, SMEs involvement in risk management is not encouraging. Although ERM is known as a tool to increase shareholders' value, still not many firms have adopted this new tool to manage risks. Thus, the main objective of this paper is to propose a conceptual framework using Thong's DTOE Model (1999) in the context of ERM practices among Malaysian SMEs. The framework consist of four (4) constructs namely decision maker, technology, organization and environment. From the review of various literatures, the four constructs proposed do supported by many researches but yet still can be explore to enhance SMEs performance in Malaysia.
\end{abstract}

Keywords: Enterprise Risk Management (ERM); ERM adoption; ERM practices; SMEs Performance; Malaysian SMEs. 
INTERNATIONAL JOURNAL OF ACADEMIC RESEARCH IN BUSINESS AND SOCIAL SCIENCES Vol. 8, No. 11, Nov, 2018, E-ISSN: 2222-6990 @ 2018 HRMARS

\section{Introduction}

Small and Medium Enterprises (SMEs) play a vital role in most countries especially developing countries. Base on the World Bank Enterprise Surveys (ES) database, a study of 49,370 firms in 104 countries revealed that SMEs have the largest shares of job creation, highest sales growth and employment growth compare to large firm (Ayyagari, Demirguc-Kunt, \& Maksimovic, 2011).

In Malaysia, SMEs accounting for 98.5 percent of total business or 907,065 establishments and account for 36.3 percent of the GDP, 65.5 percent of employment and 17.6 percent of export (SME Corporation Malaysia, 2016).

According to SME Corp, SMEs in Malaysia based on new definition effective from 1 January 2014, generally are:

i) Manufacturing sectors with annual sales turnover not exceeding RM 50 million or full-time of employees not exceeding 200 workers (previously less than 25 million annual sales turnover and less than 150 workers); and

ii) Services and other sectors with sales turnover not exceeding RM 20 million or full-time employees not exceeding 75 workers (previously less than 5 million annual sales turnover and less than 50 workers).

Definition of SMEs in details by category consists of micro, small and medium establishment is as following:

Table 1: Definition of SMEs by category

\begin{tabular}{|c|c|c|c|c|c|c|}
\hline \multirow{2}{*}{ Size } & \multicolumn{2}{|c|}{ Micro } & \multicolumn{2}{|c|}{ Small } & \multicolumn{2}{|c|}{ Medium } \\
\hline & $\begin{array}{l}\text { Sales } \\
\text { Turnover }\end{array}$ & Employees & $\begin{array}{l}\text { Sales } \\
\text { Turnover }\end{array}$ & Employees & $\begin{array}{l}\text { Sales } \\
\text { Turnover }\end{array}$ & Employees \\
\hline Manufacturing & & $<5$ & $\begin{array}{c}\text { RM } 300,000 \\
\text { to } \\
<15 \text { Million }\end{array}$ & $\begin{array}{c}5 \text { to }<75 \\
\text { employees }\end{array}$ & $\begin{array}{c}\text { RM } 15 \text { Million } \\
\text { to } \\
\leq 50 \text { Million }\end{array}$ & $\begin{array}{c}75 \text { to } \leq 200 \\
\text { employees }\end{array}$ \\
\hline $\begin{array}{c}\text { Services \& } \\
\text { Others }\end{array}$ & & employees & $\begin{array}{c}\text { RM 300,000 } \\
\text { to } \\
<3 \text { Million }\end{array}$ & $\begin{array}{c}5 \text { to }<30 \\
\text { employees }\end{array}$ & $\begin{array}{c}\text { RM } 3 \text { million } \\
\text { to } \\
\leq 20 \text { Million }\end{array}$ & $\begin{array}{l}30 \text { to } \leq 75 \\
\text { employees }\end{array}$ \\
\hline
\end{tabular}

Sources: SME Annual Report 2015/16

SMEs in Malaysia have low productivity compare to large firms (SME Corporation Malaysia, 2012). In year 2014 and 2015, the productivity gap relatively high with SMEs productivity 3.3 times lower than large firms (SME Corporation Malaysia, 2016). By comparing to developed countries, SMEs in the United States and Singapore are seven and four times more productive respectively than Malaysian SMEs (SME Corporation Malaysia, 2012).

Productivity issues are similar to most of SMEs in developing countries (Ayyagari et al., 2011). Low productivity is one of the symptom of SMEs failure or crisis (Ropega, 2011a) and part of the risk. In general SMEs face risks externally and internally. Externally, business is changing quickly and generating a great deal of uncertainty such as changing customer tastes, new product development 
INTERNATIONAL JOURNAL OF ACADEMIC RESEARCH IN BUSINESS AND SOCIAL SCIENCES Vol. 8, No. 11, Nov, 2018, E-ISSN: 2222-6990 @ 2018 HRMARS

and technology. Internally, SMEs face the risks such as human error, fraud, system failure, the disruption of production and so on (Dickinson, 2001). This environment forces firms, especially SMEs to be innovative and constantly review their processes and practices in order to keep survive (Bahri, St-Pierre, et al., 2011).

Therefore in order to manage risks, Enterprise Risk Management (ERM) could be a solution to SMEs. Given the size and managerial structure of SMEs, the process of establishing and using ERM is relatively simple given the close relationship between owners, managers and operators of the enterprise (Smit, 2012).

The main objective of this paper is to propose a conceptual framework on the determinants of ERM practices by SMEs in Malaysia using Thong's DTOE Model (1999). This theory was extended from Tornatzky and Fleischer's TOE theory (1990) where Thong argued that SME have highly centralized structured, where the owner-managers make most of critical decisions and this decision maker influences risk perception (Grant, Edgar, Sukumar, \& Meyer, 2011). As such, Thong (1999) conceptualized and verified the importance of a fourth dimensions (besides technological, organizational, environmental) which has been classified as CEO's characteristics or decision makers (D) ( Syahida \& Azwadi, 2013).

\section{Problem Statement}

In Malaysia, ERM practices still at early stages. Among current practices such as government initiative to introduce the Malaysian Code of Corporate Governance 2012 which is required the board of public listed company in Bursa Malaysia to identify principle risks and ensuring the implementation of appropriate internal control and mitigation measures (Securities Commission Malaysia, 2012). Despite of the regulation upon public listed company in Malaysia to implement risk management, the adoption rate is still relatively low compare to the other developed countries (Togok, 2016; Yazid, Hussin, \& Daud, 2011).

Event related to risk has terrible effect on SMEs than in large firms (Kiew \& Angeline, 2016). Hence, risk management is a major issues for SME (Brustbauer, 2016). Although ERM is an effective proactive risk prevention tool for SMEs (Vadiveloo \& Aguirre, 2013), the ERM practices among Malaysian SMEs are still questionable. For example there is a risk issues on fraud in business organization in Malaysia but they tend to put the matter a side (Shanmugam, Ali, Hassan, \& Haat, 2012). Furthermore only small numbers of SMEs in Malaysia are expanding into larger establishment. SMEs are afraid of taking risk and facing uncertainties when they become large corporation (Salleh \& Ibrahim, 2011).

Besides growing in size of establishment, SMEs need to face the challenges such as vulnerability in financial market, political instability, raising cost of energy and frequent natural disaster that would directly affect the future direction and growth of SMEs (Mohd Said, 2009). Therefore, ERM is crucial to be implemented by SMEs to reduce exposure to business loss (Kiew \& Angeline, 2016). Hence, it is important to study ERM in the context of SMEs in order to understand the practice of ERM to encourage adoption of ERM among non-adopter and to extent the use of ERM at its full potential.

Although the study of ERM practices is increasing recently, it is still limited (Amalina, Abdullah, Zakuan, Khayon, \& Ariff, 2012; Ekwere, 2016; Razali \& Tahir;, 2011). SMEs risk management has not 
received desired attention in the literatures (Gorzeń-Mitka, 2013; Yusuf \& Dansu, 2013). Literatures of ERM practices among SMEs in Malaysia are still lacking (Kiew \& Angeline, 2016). The majority of studies examined SMEs in developed European Countries (Falkner \& Hiebl, 2015)., Moreover, the previous study also show that the relation between performance of the firms and ERM is completely limited and it is not a measurement for ERM (Nickmanesh, Zohoori, Musram, \& Akbari, 2013). Therefore is still a need to study on the adoption factors of ERM among SMEs and its performance and to propose a conceptual framework to ease the extent and future research of ERM practices among SMEs. Hence this study will fill the gap in literature.

Malaysian SMEs need to innovate to keep competitive (SME Corporation Malaysia, 2012, 2016). Therefore this research will apply the Technological-Organizational-Environmental (TOE) framework. This framework has been introduced by Tornatzky and Fleischer (1990) is widely used in research to relate an organization with adoption of technology such as enterprise application (EA) (Kawalek \& Ramdani, 2007; Ramdani, Chevers, \& Williams, 2013) and E-Commerce (EC) (Alzougool \& Kurnia, 2008; Awa, Emecheta, \& Ojiabo Ukoha, 2012) but it is scarce to find research that use TOE Framework to examine the relationship among factors that influence the adoption of ERM by SMEs. Moreover, TOE is a model at firm level (Oliveira \& Martins, 2011). Therefore it is more suitable to be used for organization based research.

In order to distinguish between SMEs with large firms where owner-manager or decision maker have more influence (Grant et al., 2011) in adoption process, this study will use DTOE framework that is evolved from TOE framework. This framework introduced particularly for SMEs known as Thong's DTOE model. It has been used by (Thong, 1999; Wan Nur Syahida and Azwadi, 2013) to propose a specialized model for SMEs in adoption of information system such as accounting system. Hence, this research will be among the first to use DTOE in relationship to ERM adoptions among SMEs in Malaysia.

Details of the variables of this study are as following:

\subsection{Decision Maker Context}

SMEs have highly centralized structure (Thong,1999) and as a decision maker, top management usually refer to the chief executive officers (CEO's) or owner managers of the firm (Wan Nur Syahida \& Azwadi, 2013) has made most of the critical decisions. The decisions made including the daily functions or activities to future investments. The most crucial factor for small firms seems to be a very strong relationship between the company and its owner, which entails the consequences in all areas of the company, especially in the early stages of development (Ropega, 2011b).

\subsection{Technological Context}

Technological context describes both the internal and external technologies relevant to the firm (Oliveira \& Martins, 2011) It includes current practices and equipment internal to the firm, as well as the pool of available technologies external to the firm (Tornatzky and Fleischer, 1990). System integration in technology enhance firms with enterprise-level data management, robust business and data analytic, straight-through transaction processing and more effective reporting and information sharing (Lam, 2014) 
INTERNATIONAL JOURNAL OF ACADEMIC RESEARCH IN BUSINESS AND SOCIAL SCIENCES

Vol. 8, No. 11, Nov, 2018, E-ISSN: 2222-6990 @ 2018 HRMARS

\subsection{Organizational Context}

Organizational context refers to descriptive measures about the organization such as scope, size and managerial structure (Oliveira \& Martins, 2011). This context also refers to the characteristic and resources of the firm including linking structures between employees, intrafirm communication process, firm size, and the amount of slack resources (Baker, 2011).

\subsection{Environmental Context}

The environment context is the arena which the firm does business (Tornatzky and Fleischer, 1990). This arena includes industry, competitors and dealings with the government (Oliveira \& Martins, 2011). In addition, the presence or absence of technology services provider and the regulatory environment are also included in the environment context (Baker, 2011)

\subsection{Firm Performance}

Firm performance is refers to the success of a firm in the market with different outcomes. It is a focal, complex and multidimensional phenomenon. Performance itself can be characterized as the firm's ability to create acceptable outcome and actions (Philip, 2011). Firm performance includes financial and non-financial measurement (Laitinen \& Chong, 2006)

\section{Methodology}

This paper thoroughly reviews previous relevant literature in order to propose a conceptual framework that determines ERM adoption among SMEs in Malaysia. DTOE framework would be used to develop a conceptual model that link relevant factors that determine SMESs in implementing ERM.

\section{Literature Review}

In the literature the name ERM is sometimes replaced by synonyms like Enterprise-Wide Risk Management, Holistic Risk Management, Integrated Risk Management and Strategic Risk Management. Enterprise Risk Management (ERM) has emerged as a new risk management technique aimed at managing the portfolio of risks facing an organization in an integrated, enterprise-wide manner. Unlike traditional risk management, where individual risk categories are managed from a silo-based perspective, ERM involves a holistic view of risks allowing business to take into account correlations across all risk classes (Monda \& Giorgino, 2013)

In general ERM is known as a systematically integrated and discipline approach in managing risks within organizations to ensure firms achieves their objective which is to maximize and create value for their stakeholder (Razali \& Tahir, 2011). Many organizations are implementing ERM process to increase the effectiveness of their risk management activities, with the prime goal of increasing stakeholder value (Beasley, Clune, \& Hermanson, 2005)

In SMEs context, according to Vadiveloo \& Aguirre (2013) ERM is a form of micro risk management and a comprehensive approach addressing risk in all functional areas and also an effective proactive risk prevention tool for SMEs.

Therefore for the purpose of this study, ERM for SMEs can be defined as;

A micro risk management that use comprehensive approach in addressing and managing risks proactively within organization with the ultimate goals to maximize stakeholder value. 


\subsection{Relation of decision maker in adopting ERM towards performance of SMEs}

Commitment of decision maker towards implementation of SMEs is crucial (Grant et al., 2011). At the level of SMEs, decision maker will be the owner of the firm. SME owners are very knowledgeable about risks and the growth strategies (Vadiveloo \& Aguirre, 2013). Although some firm will establish a risk management team, the mandate from the owner-manager is needed to make sure the organizational goal is achieved (Burnaby \& Hass, 2009).

The risk either managed by the owner themselves in case of micro enterprise or the risk owner if there is a risk management team. Within the limits of the risk owner's accountability, the risk owner decides either to accept the risk as is or to take further steps to mitigate it. If the risk owner accepts the risks as is, the risk is monitored and reviewed in the normal future course of risk management processes. If the risk owner decides to mitigate the risk, the process of risk mitigation is defined (Aabo et al., 2001).

Furthermore, strategic risk management enables SME owner-managers to objectively evaluate their actions (Yolande Smit, 2012). Committee for Sponsoring Organization of the Treadway Commission (COSO) notes that value is created and performance is enhanced by management decision. Examples of the decisions made by management include considering the risk appetite, setting objectives, identifying risks, identifying risk responses, considering risk alternatives, and assessing capital needs for the risks (Gates, Nicolas, \& Walker, 2012).

\subsection{Relation of technology in adopting ERM towards performance of SMEs}

Technology provides relative advantages to SMEs. Technology change leads to the introduction of new products, changes in methods and organization of production, changes in the quality of resources and products, new ways of distributing the products and new way of storing and disseminating information.

Nowadays, one of the important technologies that possess by SMEs is information communication technology (ICT). The use of ICT has grown and changed with increasing rapidity, its adoption can be related to not only multinational corporation but also SMEs (Maguire, Koh, \& Magrys, 2007). However the decision on the choice and the implementation of technology in SMEs are different from those in larger firms. Without knowing the important of adopting technology, SMEs may be expending their limited resources and energy on less important factors (Grant et al., 2011).

In ERM, information and database of risks is important and part of the need to top management makes sound decision associated with risks. For a database of risks to be useful, the information possessed by people within the organization must be collected, made comparable, and continuously updated. SMEs must be able to communicate common risk across all of their businesses to analyze and manage those risks effectively (Nocco \& Stulz, 2006).

Technology has a very big impact upon SMEs and has an important effect on the level and type of investment that takes place in an economy and contribute to economic growth (Philip, 2011). Competitive advantages from the use of technology will help SMEs to outperform larger firms (Chong \& Pervan, 2007). 
INTERNATIONAL JOURNAL OF ACADEMIC RESEARCH IN BUSINESS AND SOCIAL SCIENCES

Vol. 8, No. 11, Nov, 2018, E-ISSN: 2222-6990 @ 2018 HRMARS

\subsection{Relation of organization in adopting ERM towards performance of SMEs}

Organizational readiness is a requisite to make sure ERM can be implemented and practices efficiently. As an organization's size increases, the scope of events threatening it is likely to differ in nature, timing, and extent. In addition to having a greater need for more effective enterprise-wide risk management techniques, larger entities may have greater ability to implement ERM due to greater resources (Beasley et al., 2005). Employees' knowledge of ERM is important as they are part of the organizations. As one of distinctive features of ERM is its integrated approach, adequate organization choices are fundamental to spread the risk culture, to gain commitment to the program from the personnel, and to guarantee that the ERM process is effected in the correct way and policies and procedures are respected (Monda \& Giorgino, 2013).

\subsection{Relation of environment in adopting ERM towards performance of SMEs}

Uncertainty about environmental and organizational variables reduces the predictability of corporate performance, that is, increases risk. The general environmental uncertainties correspond to factors that affect the business context across industries. General environment uncertainties include political instability, government policy instability, macroeconomic uncertainties, social uncertainties, and natural uncertainties (Miller, 2013). The environment is what gives SMEs their means of survival; satisfied customers are what keep an organization in business. However the environment is also the resource of threat. For example hostile shifts in market demand, new regulatory requirements, revolutionary technologies or the entry of new competitors (Philip, 2011).

\section{Conceptual Framework}

Enterprise risk management practices among SMEs in Malaysia can be seen through the adoption and extended use of ERM in the organizations. From the review of literature, a conceptual framework using Thong's DTOE model will explain clear determining factors of ERM adoption by SMEs.

Figure 1: Framework of adopters of ERM in SMES

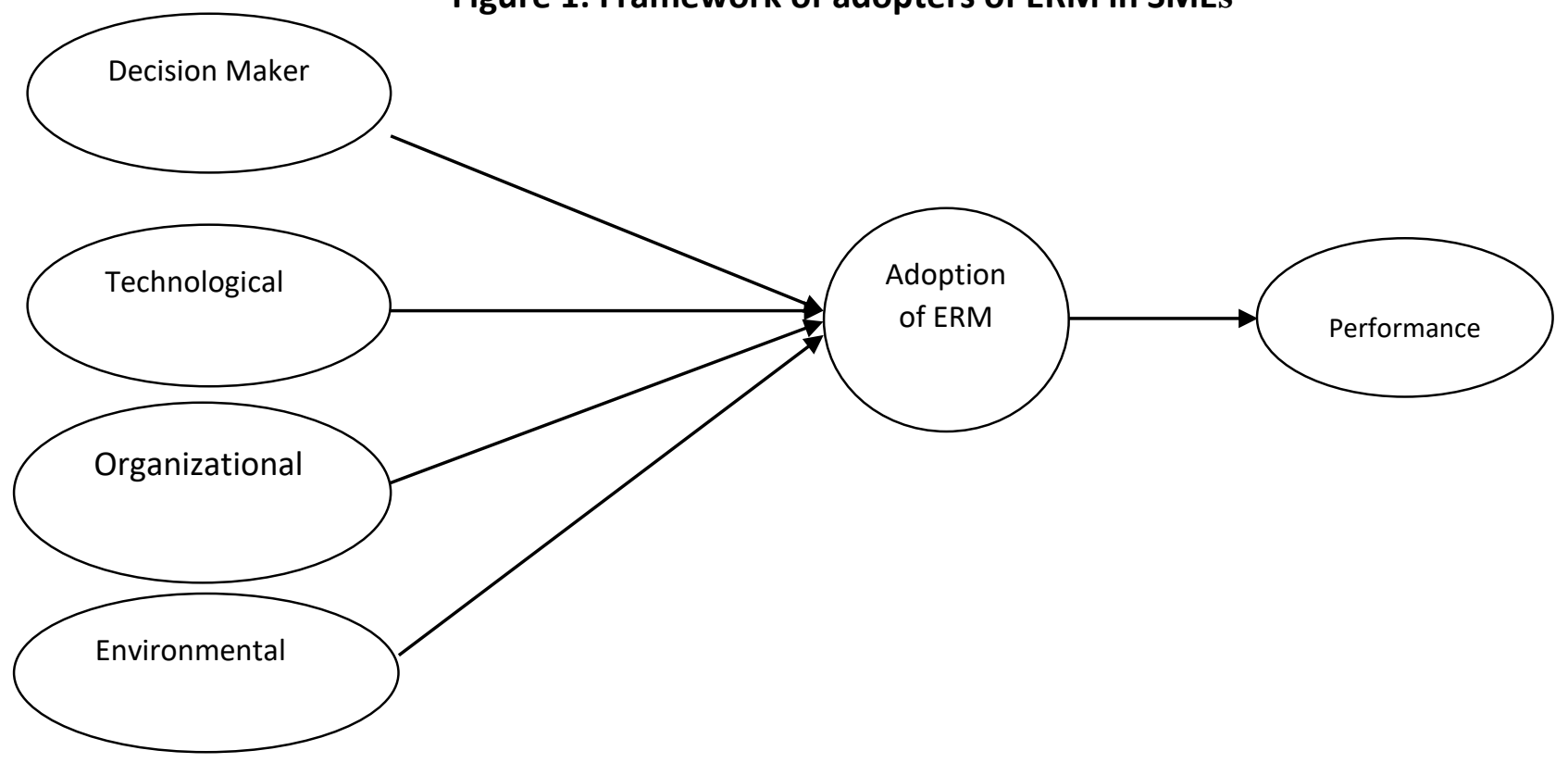


INTERNATIONAL JOURNAL OF ACADEMIC RESEARCH IN BUSINESS AND SOCIAL SCIENCES

Vol. 8, No. 11, Nov, 2018, E-ISSN: 2222-6990 @ 2018 HRMARS

\section{ERM and Performance}

In adopting ERM there are various finding that indicate the relation between ERM and firm performance. ERM is presumed to lower a firm's overall risk of failure and thus increase the performance by adopting a systematic and consistent approach to managing the risk holistically (Gordon, Loeb, \& Tseng, 2009).

In general companies that adopt an ERM approach have experienced significant improvements in business performance (Lam, 2014). However these companies mostly are financial companies since ERM at beginning is practiced by financial industry.

Financial companies are found to adopt ERM not only because of the compliance to corporate governance but also good business practices and improved decision making. This contributes to their business survival and value creation. In contrast the non-financial public listed companies in Malaysia are found to adopt ERM because of corporate governance (Manab, Kassim, \& Hussin., 2010).

Despite of the finding, there is still non-financial aspect such as high morale among staffs and fellow employees, motivation and continuous desire to excel at workplace are elements of EWRM program as a value-added tool (Hussin, Yazid, \& Razali, 2012).

In addition ERM can enhance and improve performance of audit and risk management executives in identifying risks events and manage related risks from other agencies and regulating bodies (Hudson, Smart, \& Bourne, 2001).

As companies implement an ERM process, the new knowledge it offers them such as objectives, risks, oversight, information and communication, and the internal environment leads to enhanced management, as evidenced by increased management consensus, better informed decisions, better communication with management regarding risk taking, and increased management accountability. This enhancement leads to improved performance (Gates et al., 2012; Heneghan, 2008).

\section{Significant of the Study}

The significance of this research is as follows:

First, specifically, this research examines the critical factors that encourage willingness of nonadopters of SMEs to adopt ERM, the critical factors that influence the extent of ERM adoption among adaptors of ERM in SMEs, and whether adoption of ERM affects the firm's overall performance of SMEs. Unlike most of the previous studies only focused on certain industries such as manufacturing (Mohd Idris \& Abdullah, 2013), financing (Abdul Rasid \& Abdul Rahman, 2009) and public listed company (Razali, Yazid, \& Mohd Tahir, 2011), this research will mainly focus on SMEs across industries.

The managerial methods developed for large firms do not necessarily applied for SMEs (Mazzarol \& Volery, 2015). Therefore in discussing theory development for SMEs, D'Amboise \& Muldowney (1988) recommended that scholars look for relationship and strive for a more global view encompasses general framework such as task environment, organizational configuration and managerial characteristics. Moreover, since previous research on ERM practices among SMEs done focusing on respondent from certain industries, the ability to generalize the result across industries will be valuable to contribute to the body of knowledge (Kiew \& Angeline, 2016).

Second by identifying the factors that influence the willingness to adopt ERM among non-adopters, this study is significant as its finding would contribute some valuable information that could be used 
INTERNATIONAL JOURNAL OF ACADEMIC RESEARCH IN BUSINESS AND SOCIAL SCIENCES

Vol. 8, No. 11, Nov, 2018, E-ISSN: 2222-6990 @ 2018 HRMARS

by relevant parties to remedy existing or devise appropriate plans to encourage the non-adopters to adopt Enterprise Risk Management (ERM) in near future.

Third, by examining the factors that influence the extent of ERM adoption among adopters, the finding is significant in giving a view on SMEs and relevant parties as to why the ERM is not utilized at full potential.

Fourth, the finding of this study could also assist stakeholders in promoting ERM as a tool to enhance firms' performance. Mazzarol and Volery (2015) highlighted from their analysis of 660 articles published in 30 years that SMEs have a unique characteristic compare to large firms and a research for this type of establishment must be relevant to actual business management.

\section{Conclusions}

The study, therefore, comes to conclude that ERM have an impact on the organization performance. However, among the key findings of the study proposed the relationship between decision maker, technology, organization and environment towards ERM adoption by SMEs.

Several studies have been conducted in relating the effect of ERM on organization performance (Gates et al., 2012; Hudson et al., 2001; Kiew \& Angeline, 2016). Hence, the adoption of ERM is expected to add value to SMEs.

Thus, future study on the adoption of ERM could be undertaken in order to test the suggested research framework. A survey questionnaire could be used to collect data from Malaysian SMEs across industries. The data will be analyzed using Statistical Package for Social Science (SPSS) software to conduct reliability test, and descriptive analysis (Sekaran, 2003) and using Structural Equation Modeling (SEM) in confirming the relationships among factors (Hair, Sarstedt, Pieper, \& Ringle, 2012) as illustrated in DTOE framework. As proposed by Brustbauer (2016), testing the structural model using SEM in ERM and SMEs study will be a valuable contribution to the body of knowledge. This new study could enhance our understanding relating to ERM implementation and the findings could assist SMEs to improve their performance.

\section{References}

Aabo, T., Fraser, J. R. S., Simkins, B. J., Beasley, M. S., Clune, R., Hermanson, D. R., ... Rot, A. (2001). The Rise and Evolution of the Chief Risk Officer: Enterprise Risk Management at Hydro One. Journal of Risk Management of Korea, 6(3), 531-556. https://doi.org/10.1016/j.jaccpubpol.2005.10.001

Alzougool, B., \& Kurnia, S. (2008). Electronic Commerce Technologies Adoption by SMEs : A Conceptual Study. Australasian Conference on Information Systems, 1-10.

Amalina, N., Abdullah, M., Zakuan, N., Khayon, M., \& Ariff, M. S. (2012). Adoption of Enterprise Risk Management Practices in Organization : A Review. International Journal Business \& Information Technology, 2(1), 1-9. Retrieved from http://excelingtech.co.uk/

Awa, H. O., Emecheta, B. C., \& Ojiabo Ukoha. (2012). Integrating TAM and TOE Frameworks and Expanding their Characteristic Constructs for E-Commerce Adoption by SMEs Electronic Commerce ( EC ). Informing Science \& IT Education Conference (InSITE), 18.

Ayyagari, M., Demirguc-Kunt, A., \& Maksimovic, V. (2011). Small vs . Young Firms across the World Contribution to Employment, Job Creation, and Growth. 
INTERNATIONAL JOURNAL OF ACADEMIC RESEARCH IN BUSINESS AND SOCIAL SCIENCES

Vol. 8, No. 11, Nov, 2018, E-ISSN: 2222-6990 @ 2018 HRMARS

Baker, J. (2011). The Technology-Organization-Environment Framework, 28(SEPTEMBER 2011). https://doi.org/10.1007/978-1-4419-6108-2

Beasley, M. S., Clune, R., \& Hermanson, D. R. (2005). Enterprise risk management: An empirical analysis of factors associated with the extent of implementation. Journal of Accounting \& Public Policy, 24(6), 521-531. Retrieved from

10.1016/j.jaccpubpol.2005.10.001\%5Cnhttp://libaccess.mcmaster.ca.libaccess.lib.mcmaster.ca /login?url=http://search.ebscohost.com/login.aspx?direct=true \&db=bth\&AN=19185873\&site= ehost-live\&scope=site

Brustbauer, J. (2016). i s b j Enterprise risk management in SMEs : Towards a structural model, (X). https://doi.org/10.1177/0266242614542853

Burnaby, P., \& Hass, S. (2009). Ten steps to enterprise-wide risk management. Corporate Governance, 9(5), 539-550. https://doi.org/10.1108/14720700910998111

Chong, S., \& Pervan, G. (2007). Factors Influencing the Extent of Deployment of Electronic Commerce for Small-and Medium-Sized Enterprises. Journal of Electronic Commerce in Organizations, 5(March).

D’Amboise, G., \& Muldowney, M. (1988). Management Theory for Small Business: Attempts and Requirements. The Academy of Management Review, 13(2), 226-240. Retrieved from http://www.jstor.org/stable/258574

Dickinson, G. (2001). Enterprise Risk Management : Its Origins and Conceptual Foundation. The Geneva Papers on Risk and Insurance, 26(3), 360-366. https://doi.org/10.1111/14680440.00121

Ekwere, N. (2016). Framework of Effective Risk Management in Small and Medium Enterprises ( SMEs ): A Literature Review, 20, 23-46.

Falkner, E. M., \& Hiebl, M. R. W. (2015). Risk management in SMEs : a systematic review of available evidence. https://doi.org/10.1108/JRF-06-2014-0079

Gates, S., Nicolas, J.-L., \& Walker, P. L. (2012). Enterprise Risk Management: A Process for Enhanced Management and Improved Performance. Management Accounting Quarterly, 13(3), 28-38. Retrieved from http://ezproxy.library.capella.edu/login?url=http://search.ebscohost.com/login.aspx?direct=tr ue $\& d b=b$ th \&AN=78173163\&site=ehost-live \&scope=site

Gordon, L. a., Loeb, M. P., \& Tseng, C. Y. (2009). Enterprise risk management and firm performance: A contingency perspective. Journal of Accounting and Public Policy, 28(4), 301-327. https://doi.org/10.1016/j.jaccpubpol.2009.06.006

Gorzeń-Mitka, I. (2013). Risk Identification Tools -- Polish Msmes Companies Practices. Problems of Management in the 21st Century, 7, 6-11. Retrieved from http://ra.ocls.ca/ra/login.aspx?url=http://search.ebscohost.com/login.aspx?direct=true\&db=b th\&AN=89641545\&site=bsi-live

Grant, K., Edgar, D., Sukumar, A., \& Meyer, M. (2011). “ Risky Business" : Perceptions of e-business Risk by UK Small and Medium sized Enterprises ( SMEs ), (2010), 1-18.

Hair, J. F., Sarstedt, M., Pieper, T. M., \& Ringle, C. M. (2012). The Use of Partial Least Squares Structural Equation Modeling in Strategic Management Research : A Review of Past Practices and Recommendations for Future Applications. Long Range Planning, 45(5-6), 320-340. 
INTERNATIONAL JOURNAL OF ACADEMIC RESEARCH IN BUSINESS AND SOCIAL SCIENCES

Vol. 8, No. 11, Nov, 2018, E-ISSN: 2222-6990 @ 2018 HRMARS

https://doi.org/10.1016/j.Irp.2012.09.008

Heneghan, M. (2008). Enterprise Risk Management. BA 559 Enterprise IT Governance.

Hudson, M., Smart, A., \& Bourne, M. (2001). Theory and practice in SME performance measurement systems. International Journal of Operations \& Production Management, 21(8), 1096-1115. https://doi.org/10.1108/EUM0000000005587

Hussin, M. R., Yazid, a. R., \& Razali, a. . (2012). Enterprise-wide risk management (EWRM) as a value added tool in enhancing the economic value of business enterprises. International Business Research, 5(1), 83-98.

Kawalek, P., \& Ramdani, B. (2007). SME ADOPTION OF ENTERPRISE SYSTEMS IN THE NORTHWEST OF ENGLAND: An Environmental, Technological, and Organizational Perspective, 235, 409-429.

Kiew, Y., \& Angeline, H. (2016). Enterprise Risk Management : Evidence From Small-Medium Enterprises, (March), 151-170.

Laitinen, E. K., \& Chong, G. (2006). How do small companies measure their performance? Problems and Perspectives in Management, 4(3), 49-68.

Lam, J. (2014). Enterprise Risk Management: From Incentives to Controls; Second Edition. Wiley, 2, 1-476.

Maguire, S., Koh, S. C. ., \& Magrys, A. (2007). The adoption of e-business and knowledge management in SMEs. https://doi.org/10.1108/14635770710730928

Malaysia, S. C. (2012). Malaysian Code on Corporate Governance 2012, 1-43.

Malaysia, S. C. (2012). Summary SME Masterplan 2012-2020. SME Corporation Malaysia. Kuala Lumpur. Retrieved from http://medcontent.metapress.com/index/A65RM03P4874243N.pdf

Malaysia, S. C. (2016). SME Annual Report 2015/16.

Manab, N. A., Kassim, I., \& Hussin., M. R. (2010). Enterprise-Wide Risk Management (EWRM) Practices_Between Corporate Governance Compliance and Value Creation. International Review of Business Research Papers, 6(2), 239-252.

Mazzarol, T., \& Volery, T. (2015). The Evolution of the Small Business and Entrepreneurship Field : A Bibliometric Investigation of the Articles Published ... International Small Business Journal, 33 (4)(June), 374-396. https://doi.org/10.1177/0266242613516139

Miller, K. D. (2013). A Framework for Integrated Risk Management in International Business. Journal of International Business Studies, 23(2), 311-331.

Mohd Said, S. (2009). SMEs in The Malaysian Economy. SSRN Electronic Journal, 1(2). https://doi.org/10.2139/ssrn.1851426

Monda, B., \& Giorgino, M. (2013). An ERM Maturity Model. Professional Risk Managers' International Association, Society of Actuaries, 32, 1-23.

Nickmanesh, S., Zohoori, M., Musram, H. A. M., \& Akbari, A. (2013). Enterprise Risk Management and Performance in Malaysia. Interdisciplinary Journal of Contemporary Research in Business, 5(1), 670-707.

Nocco, B., \& Stulz, R. (2006). Enterprise Risk Management: Theory and Practice. Journal of Applied Corporate Finance, 18(4), 8-20.

Oliveira, T., \& Martins, M. (2011). Literature review of information technology adoption models at firm level. The Electronic Journal Information ..., 14(1), 110-121. Retrieved from http://www.researchgate.net/publication/258821009_Literature_Review_of_Information_Tec 
INTERNATIONAL JOURNAL OF ACADEMIC RESEARCH IN BUSINESS AND SOCIAL SCIENCES Vol. 8, No. 11, Nov, 2018, E-ISSN: 2222-6990 @ 2018 HRMARS

hnology_Adoption_Models_at_Firm_Level/file/9c960528fdf0cc370b.pdf

Philip, M. (2011). Factors Affecting Business Success of Small \& Medium Enterprises (SMEs). Amity Global Business Review, 6(1), 118-136. https://doi.org/10.5539/ass.v7n5p180

Ramdani, B., Chevers, D., \& Williams, D. a. (2013). SMEs' adoption of enterprise applications: A technology-organisation-environment model. Journal of Small Business and Enterprise Development, 20(4), 735-753. https://doi.org/10.1108/JSBED-12-2011-0035

Razali, A. R., \& Tahir;, L. M. (2011). Review of the Literature on Enterprise Risk Management. Business Management Dynamics, 1(5), 08-16.

Razali, A. R., \& Tahir, L. M. (2011). Review of the Literature on Enterprise Risk Management. Business Management Dynamics, 1(5), 08-16.

Ropega, J. (2011a). The Reasons and Symptoms of Failure in SME. International Advances in Economic Research, 17(4), 476-483. https://doi.org/10.1007/s11294-011-9316-1

Ropega, J. (2011b). The Reasons and Symptoms of Failure in SME. International Advances in Economic Research, 17(4), 476-483. https://doi.org/10.1007/s11294-011-9316-1

Salleh, F., \& Ibrahim, M. D. (2011). Demographic Characteristics Differences of Risk Taking Propensity among Micro and Small Business Owners in Malaysia. International Journal of Business and Social Science, 2(January), 149-153.

Sekaran, U. (2003). Research Methods For Business (Fourth Edi). John Wiley \& Sons, Inc.

Shanmugam, J. K., Ali, A., Hassan, M., \& Haat, C. (2012). Internal Control, Risk Management and Fraud Prevention Measures on Smes : Reliability and Validity of Research Instrument. International Conference on Business and Economic Research, (March), 475-494.

Thong, J. Y. L. (1999). An Integrated Model of Information Systems Adoption in Small Businesses, 15(4), 187-214. Retrieved from http://papers.ssrn.com/sol3/papers.cfm?abstract_id=1977980

Togok, S. (2016). Factors Influencing The Effectiveness of Enterprise Risk Management (ERM) in Public Listed Companies. Universiti Malaya.

Vadiveloo, J., \& Aguirre, M. (2013). Enterprise Risk Management - Small \& Medium Sized Enterprises. In 2013 International Acturial Conference (pp. 1-31). Medellin, Colombia: Towers Watson.

Wan Nur Syahida, W. I., \& Azwadi, A. (2013). Conceptual Model for Examining the Factors That Influence the Likelihood of Computerised Accounting Information System ( Cais ) Adoption Among Malaysian Smes It / Is Adoption. Journal of Information Technology and Business Management, 15(1), 122-151.

Yazid, A. S., Hussin, M. R., \& Daud, W. N. W. (2011). An Examination of Enterprise Risk Management (ERM) Practices among the Government-Linked Companies (GLCs) in Malaysia. International Business Research, 4(4), 94-103. https://doi.org/10.5539/ibr.v4n4p94

Yolande Smit. (2012). A literature review of small and medium enterprises (SME) risk management practices in South Africa. African Journal of Business Management, 6(21), 6324-6330. https://doi.org/10.5897/AJBM11.2709

Yusuf, T. O., \& Dansu, F. S. (2013). Smes, business risks and sustainability in nigeria. European Journal of Business and Social Sciences, 2(9), 76-94. Retrieved from http://www.ejbss.com/Data/Sites/1/vol2no9december2013/ejbss-1312-13smes, businessrisksandsustainabilityinnigeria.pdf 